\title{
Main Title Residential space differentiation and social integration of typical settlements in the typical area of Beijing second Green Belt - a case study of three communities in Cuigezhuang Township
}

\author{
Yuting Li, Affiliation, China
}

First name SURNAME, Beijing Forestry University, Country

\begin{abstract}
Beijing second Green Belt is located in the urban-rural fringe area. Under the background of rapid urbanization, due to the unclear planning and control guidance for a long time, Beijing second Green Belt provides a large number of cheap rental houses for the migrant population, becoming the main base area for the migrant population. This article selects CuiGeZhuang Township

(typical villages of Beijing second Green Belt) and towns as the research object, through field investigation and questionnaire investigation, interview method, social integration system reveals the migrant population and influence mechanism between the residential differentiation, diagnosis recognition under different types of living space, the key factors of residents' social integration, refining promoting population control measures of social integration and optimization of path. It is found that there are five types of diversified and fragmented settlement space for foreign residents in Cuigezhuang township left by the early housing policy: rural self-built house, residential area, commercial housing area, unit public housing area and high-grade villa area. The degree of social integration of migrants in different residential space types in the same village is significantly different. The social integration degree of "unit compound" and "returning residential area" is the highest, the social integration degree of residents in "commodity residential area" is relatively low, and the social integration degree of "rural self-built housing" is the lowest, basically showing the social interaction dimension integration, psychological dimension integration, social participation dimension integration, economic work dimension integration in descending order. In different types of residential space, the factors that affect the social integration of foreign residents are different, including public security, sanitary environment, public space utilization rate, living time, transportation convenience and other residential factors, as well as Beijing second Green Belt control policy factors. According to the main factors affecting the social integration of foreign residents, this paper tries to put forward four strategies: enriching the allocation of public facilities, improving the quality of living environment, strengthening community activities and participation, and perfecting the policy guarantee system, which can provide decision-making support for the sustainable development of the Beijing second Green Belt in practice.
\end{abstract}

\section{Keywords}

Residential space differentiation, social integration, Beijing second Green Belt 


\section{The introduction}

Under the background of continuous urbanization, the spatial structure and land use pattern of urban fringe are changing rapidly, and the differentiation and polarization of social space are the most important characteristics of urban fringe. A large number of migrants enter the urban fringe which provides a large number of cheap rental houses, presenting a strong residential space hybrid and heterogeneous characteristics[1-15]. In particular, Beijing second Green Belt, located at the edge of Beijing, has not only villages and settlements of aborigines, but also special villages and communities such as "express villages", "take-out villages", "ant villages" and "art villages" that accommodate migrants for employment and residence.

However, in the context of a number of institutional barriers in macro policies and planning, the vast majority of migrant population is still only a "marginal" role in urban construction and development, failing to truly enter the urban system to share the development and construction achievements of urbanization. At the same time, the living areas, conditions and environments of non-local residents are different, and the urban integration is generally not high, which leads to the differentiation in economy, identity, psychology, behavior and other aspects[15-30]. In both physical space and social space, a kind of "dualism" is displayed. The main manifestations are as follows: the high-income class preferentially chooses the residential areas with high housing quality, complete living facilities and beautiful natural environment, while the low-income class is forced to live in the residential areas with low housing quality, imperfect facilities and poor living environment. The existence of residential spatial differentiation means social inequality. Therefore, the study of residential spatial differentiation and social integration in Cuigezhuang Township, a typical area separated by, Beijing second Green Belt has become an important breakthrough point for the sustainable development of megalopolis.

\section{Methods}

This paper adopts qualitative and quantitative research methods. Qualitatively, this paper interviewed 10 local township leaders, 50 foreign occupation residents and 50 local residents to understand their basic living conditions and integration status. The questionnaire survey mainly adopts sampling survey and is directed by investigators to residents in person to fill in. A total of 350 valid questionnaires are issued, and the final valid samples are 312 . The reliability and validity are above 0.9 . The content of the questionnaire includes two aspects: (1) Age, occupation, education background and other personal information; (2) About social integration: economy, culture, social participation and social interaction, residence and work.

In quantitative aspect, STATA software was used for statistical analysis of questionnaire data. First, according to the evaluation index system of social integration, the degree of social integration is measured by relevant formulas. The second is to analyze the influence mechanism of residential space differentiation on social integration through multiple linear stepstep regression, establish the regression model of the influence relationship between residential space and residents' social integration, analyze the direction and magnitude of the influence of characteristic factors on the overall degree of residents' social integration, and analyze its mechanism.

\section{Research on the general situation and residential space types of Cuigezhuang Township}

\subsection{Overview of the study area}

The research selected Cuigezhuang township of Beijing second Green Belt as the research area(Figure 1). Cuigezhuang township covers an area of 31.5 square kilometers. It was established in 1984 and has been 
under the jurisdiction of 15 administrative villages and 4 communities since the administrative division was adjusted in 2004. Basically, the township is located in the area separated by Beijing second Green Belt. The specific types of industries near the community are diverse, covering catering, accommodation, commercial sales, finance, real estate, education and culture and other industries. However, the scale of industrial development is uneven and the scale grade distribution is discrete, showing a diversified development trend. The living environment is relatively poor compared with other parts of the city, with inadequate infrastructure and relatively low housing rents. All of these provide basic conditions for the agglomeration and life of migrant population, making it one of the urban agglomeration Spaces for migrant population.

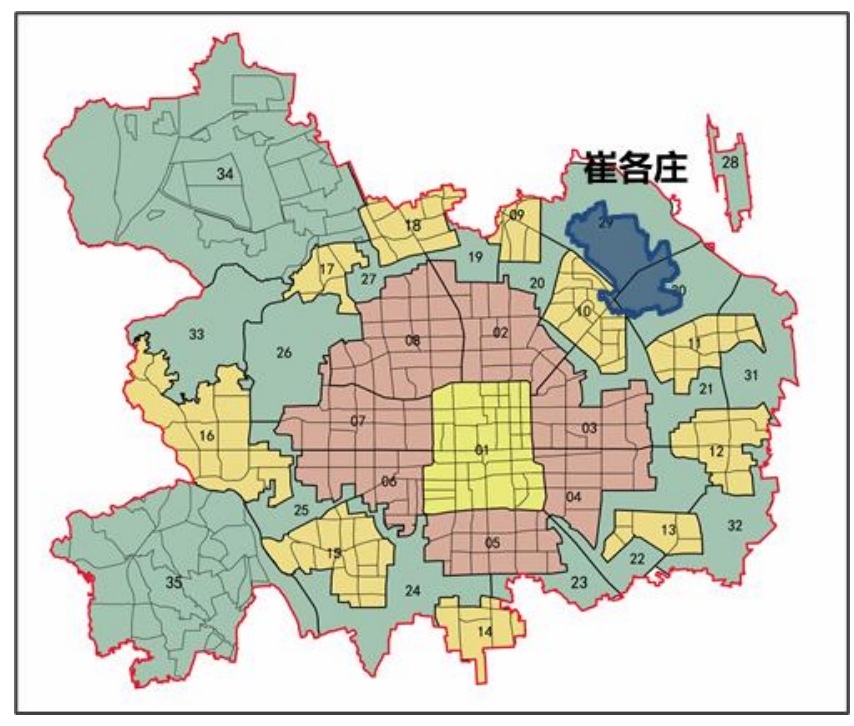

Figure 1. Location conditions of cuigezhuang Township

Source: Study on land use and socio-economic evolution of villages and towns in erdaolvge, Beijing -- Taking cuigezhuang township as an example (2010-2020)

Under the double pressure of the rapid urbanization process and the construction of Beijing second Green Belt, its land use, social structure and industrial types are highly mixed with the characteristics of urban and rural areas. The main changes can be roughly divided into three stages:(1) the changes of land use and social structure brought about by the development of central villa areas in the 1990s; (2) The township's new socialist rural reconstruction since 2007; (3) Large-scale demolition and evacuation after the pilot project of urban-rural integration started in 2009(Figure 2).

There are 36,838 registered population and 83,878 floating population in the township. The ratio of registered population to migrant population is about $1: 2.5$. On the whole, the migrant population is generally not highly educated, and the migrant population with junior middle school education occupies an absolute advantage. In terms of occupation, the proportion of service industry in tertiary industry and professional and technical personnel is relatively high(Figure 3.4). 


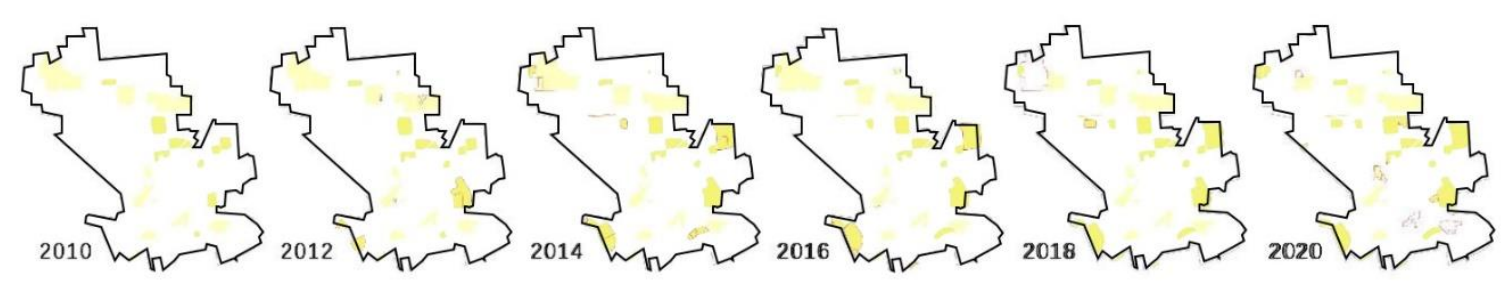

Figure 2. Evolution of residential space in cuigezhuang Township

Source: Study on land use and socio-economic evolution of villages and towns in erdaolvge, Beijing -- Taking cuigezhuang township as an example (2010-2020)

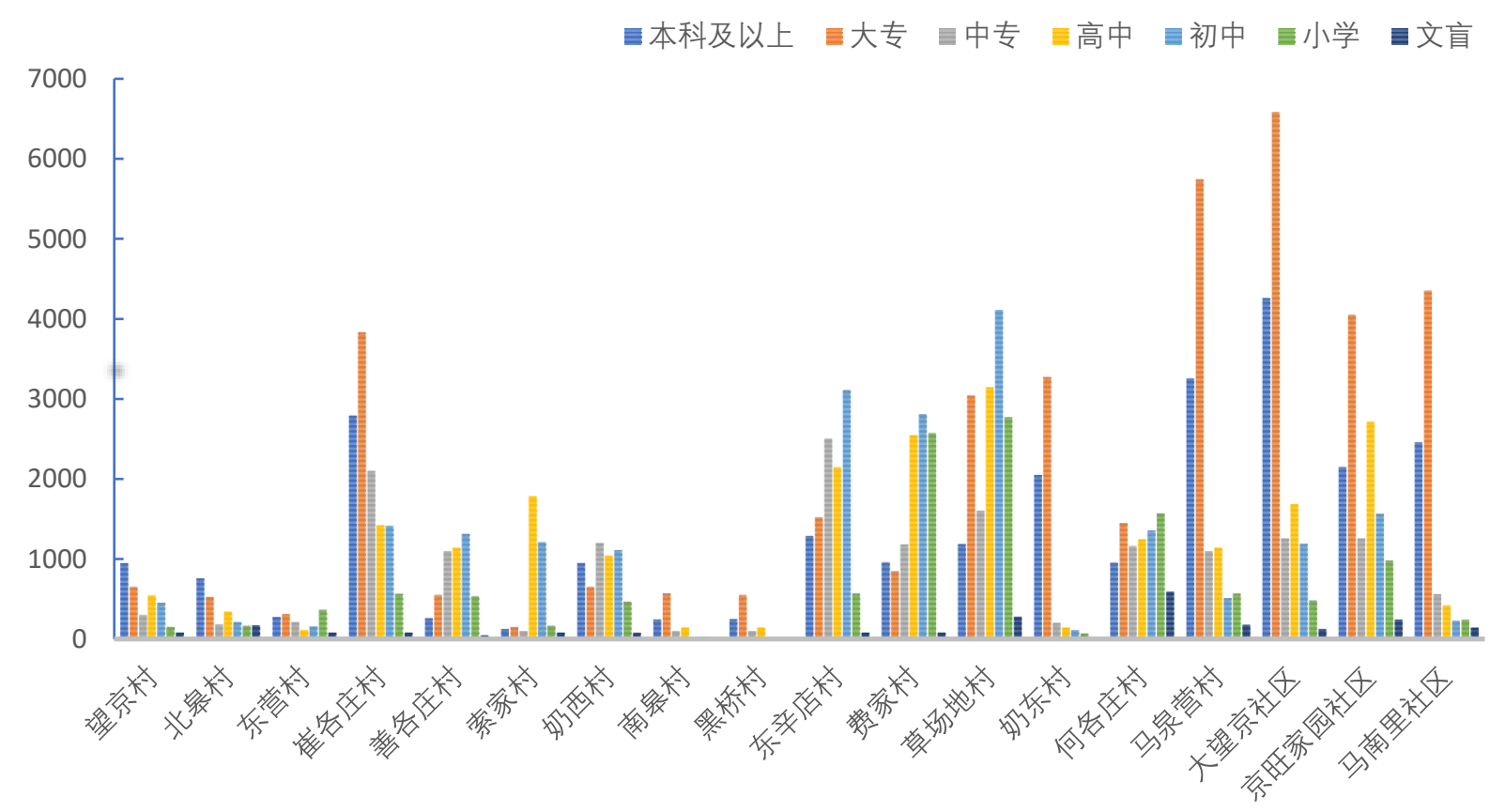

Figure 3. Educational background and cultural level of community population in cuigezhuang Township Source: self drawn 


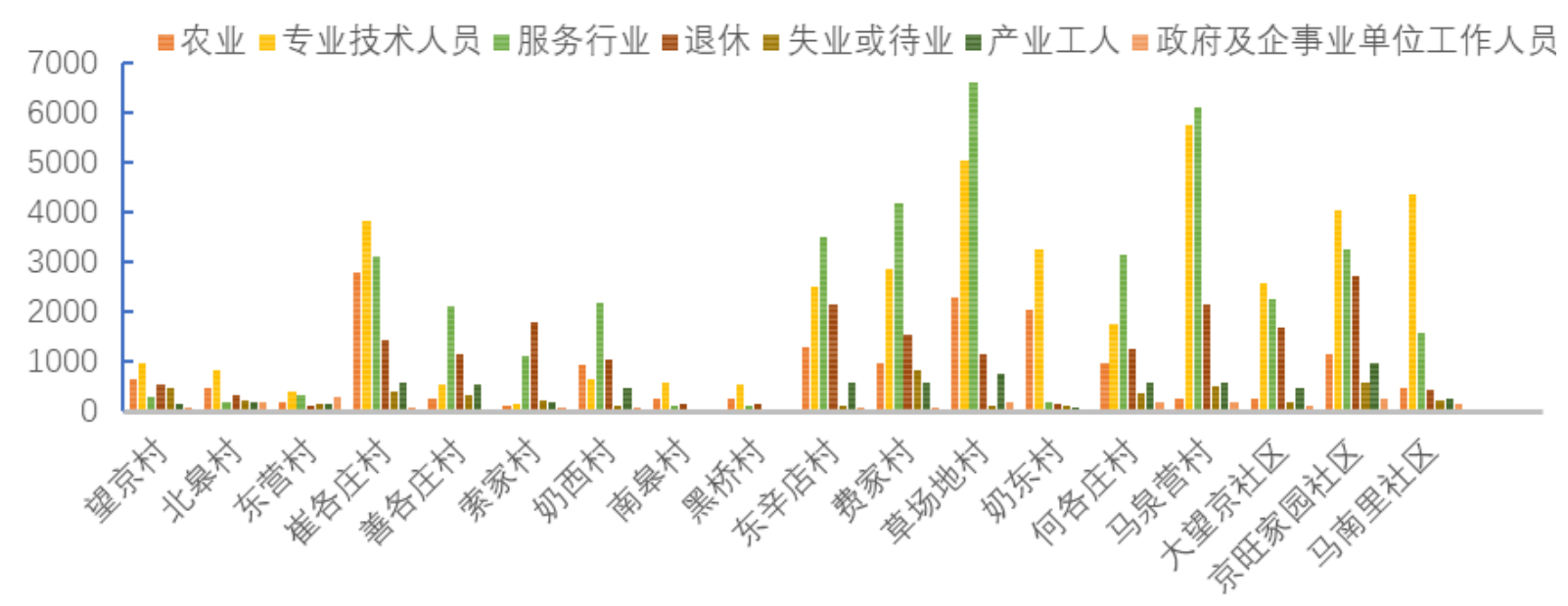

Figure 4. Population and occupation distribution of communities in cuigezhuang Township

Source: self drawn

\subsection{Types of residential space in Cuigezhuang Township}

The whole, in the process of rapid urbanization and green controlled, CuiGeZhuang Township has been "disassemble" and "restructuring" (figure 7), making the original residential type gradually replaced by a new type, still exists, but the original type and differentiation to form the mixed pluralism residents live space (figure 5), mainly divides into five types, Rural since the construction of housing, commodity housing, housing community, unit public housing community, high-grade villa area five types.

High-grade villa area concentrated distribution in eastern Cui Gezhuang township. Rural self-built houses are concentrated in the central part of Cuigezhuang township, mainly located in Hegezhuang and Feijia Village. Commercial housing is concentrated in the west and north of The town. Unit public housing community and return residential area (housing) two types of concentrated distribution in the central cui Gezhuang township. Most high-end neighborhoods and general residential areas are separated by neighborhood roads or walls, and the residential disparity between high income groups and low - and middle-income groups is very clear. 


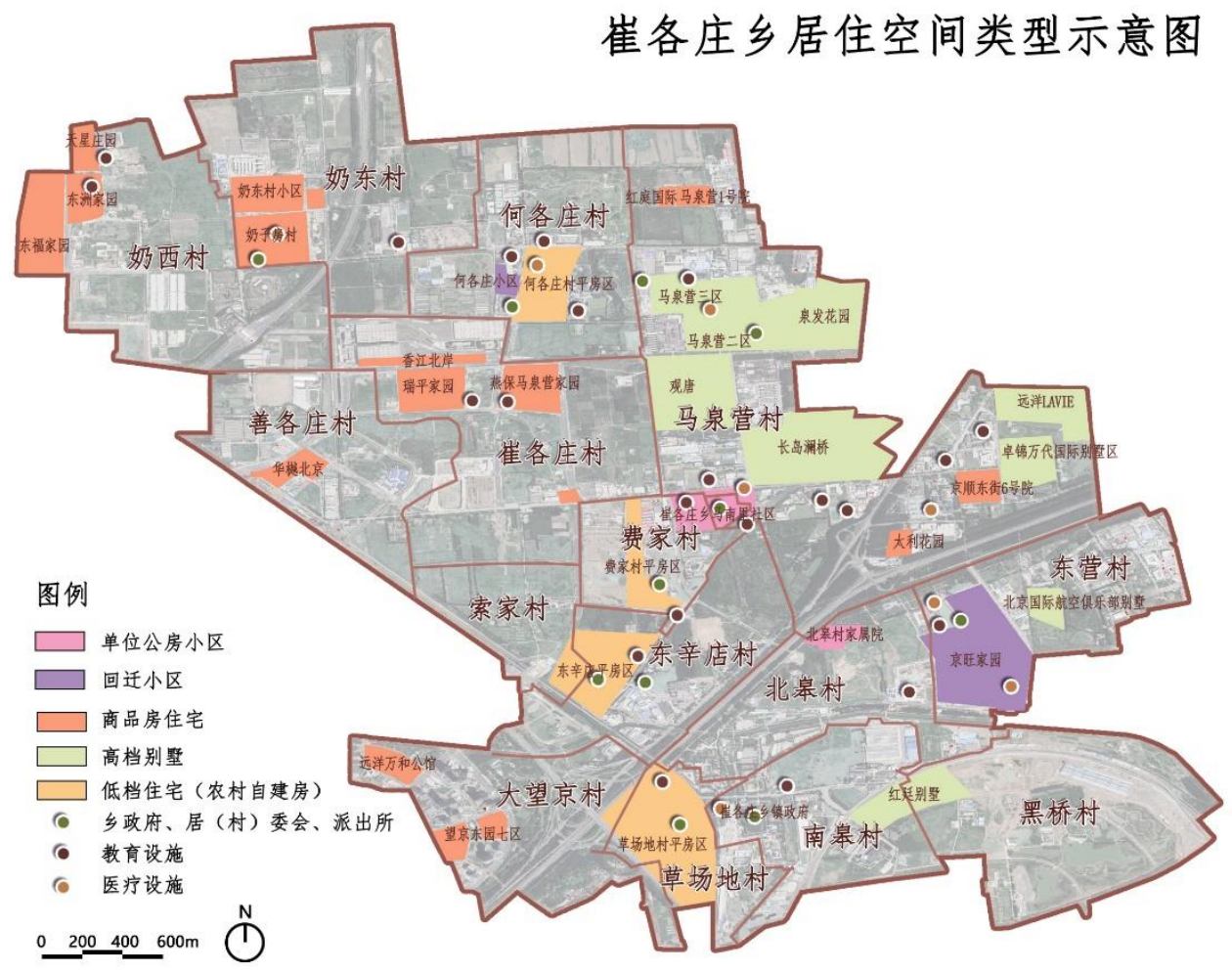

Figure 5.Schematic diagram of residential space types in Cuigezhuang Township

Source: self drawn

\section{Research on the characteristics of residential differentiation and social integration of three typical communities}

\subsection{Selection basis of typical cases}

In accordance with the purpose and content of this study, the selection of typical cases requires universality and representativeness on the whole level, and diversity and typicality on the individual level. The selected typical community should cover the living space of different types of residents, rather than just one type of living space. At the same time, the living space should be distinct and representative to a certain extent.

According to the above selection basis, this paper chooses three villages (communities) : Hegezhuang, Feijia Village (including part of Mananli community) and Jingwang Community. The cases distributed in the northern, southern and eastern CuiGeZhuang Township, among them, what area village contains low residential building (rural) and returned two types of community, fee home part contains Ma Nali village, village community of Beijing prosperous community is part of commodity house and move back room, between 2002 and 2012 construction and complete CuiGeZhuang Township residents relocation, These four communities have diversified migrant population structure and have certain representativeness and typicality. (Note: High-grade villas are not open to the public because of their strong privacy, so they cannot be investigated in detail.) (figure 6) 


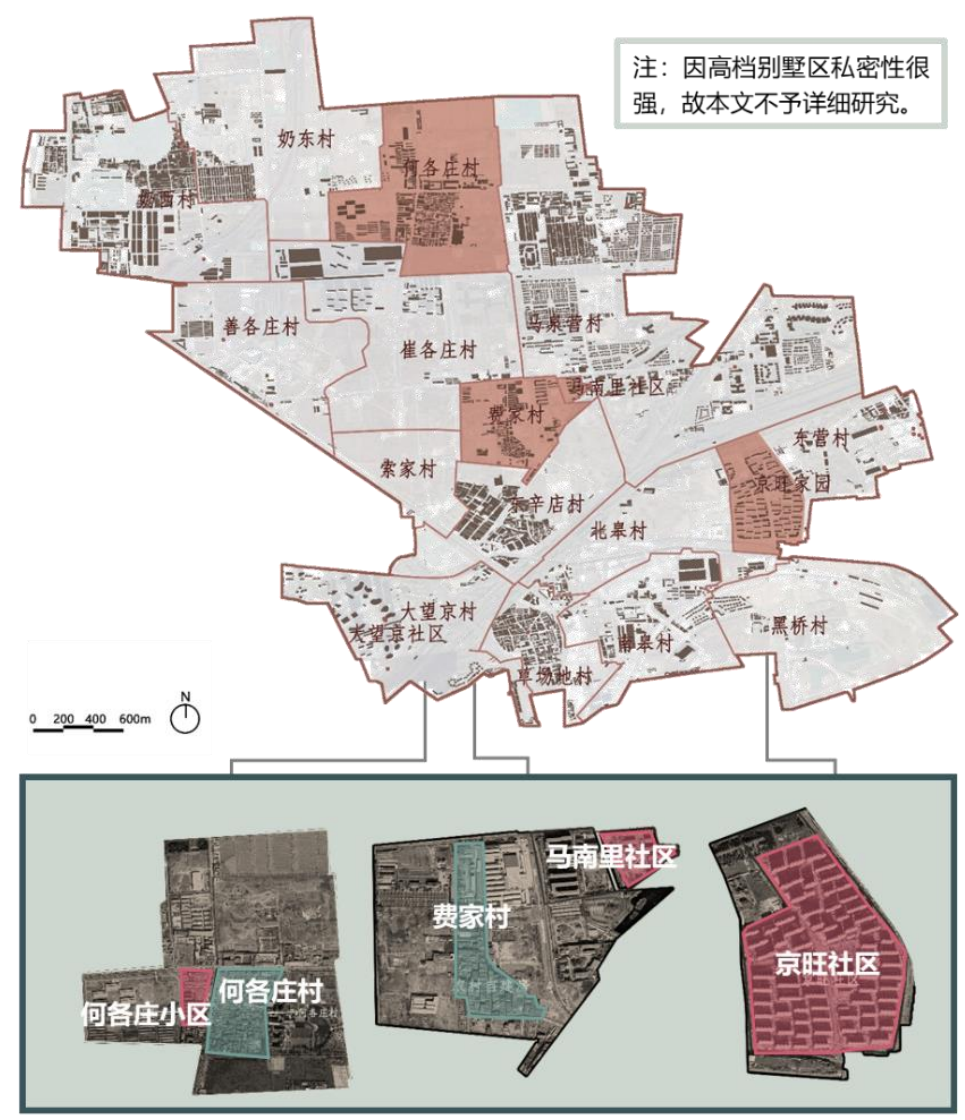

Figure 6. Typical sample villages in Cuigezhuang Township

Source: self drawn

(1) Hegezhuang Village

Hegezhuang village covers an area of 1.78 square kilometers, with more than 1100 registered population, more than 5000 migrants and more than 100 famous artists at home and abroad. Before 2006, the main economy of Hegezhuang village came from informal leasing of houses, and residents began to build houses with "tiles" economy. After 2006, driven by the cultural and economic development model, the village collective began to rent out idle land and houses in the village by taking advantage of the advantages of transportation location and rich cultural environment, and carried out the unified upgrading and renovation of "organized management of houses", which attracted a large number of art institutions and artists to settle in. (figure 7,8 )
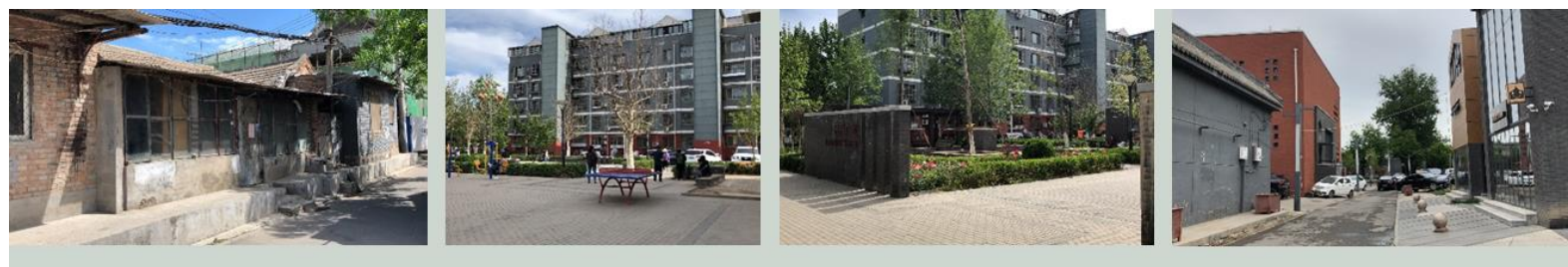

Figure 7. Real scene of Hegezhuang Village and residential area

Source: self drawn 


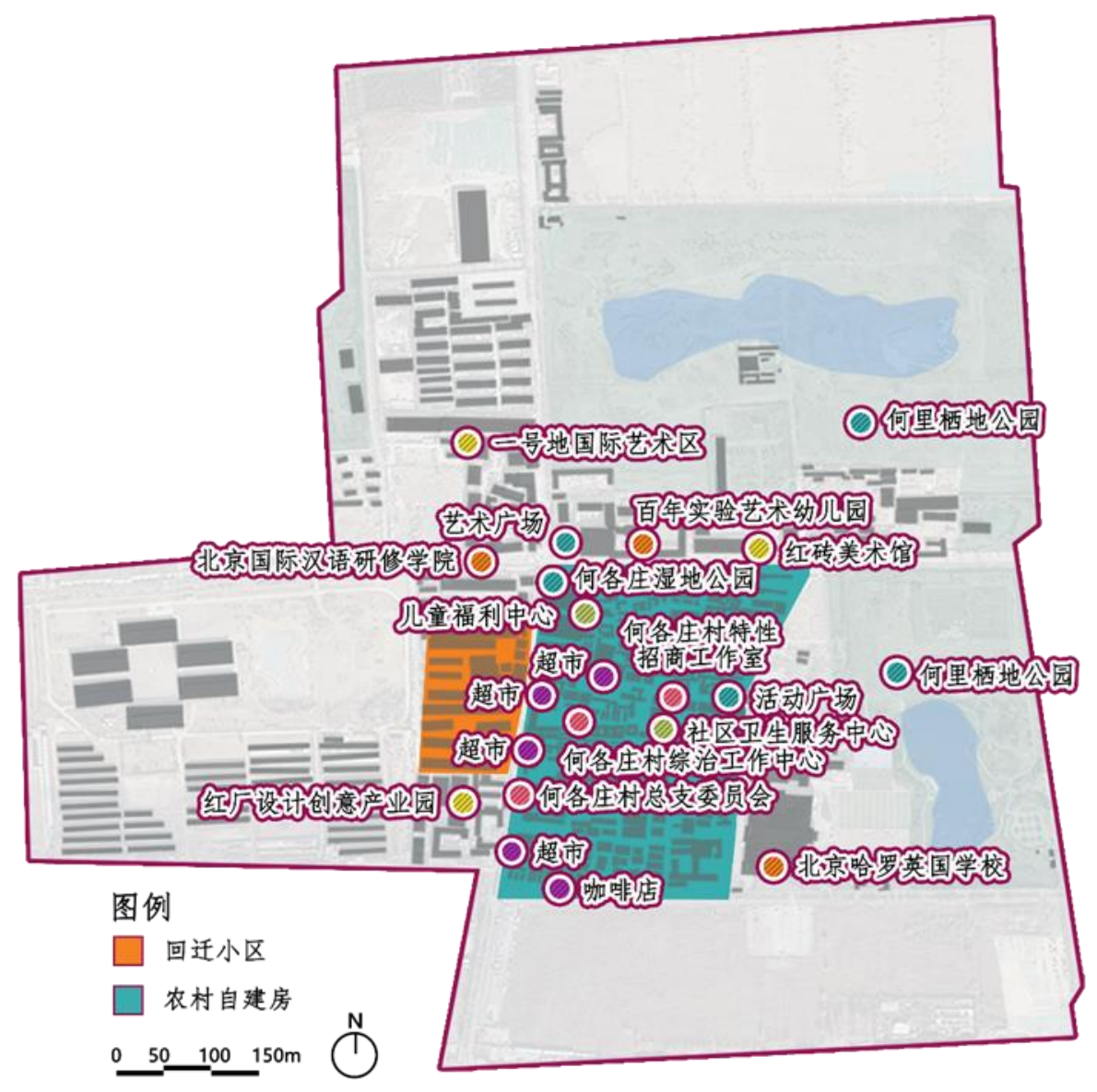

Figure 8 .Residential space differentiation and infrastructure distribution in Jingwang community

Source: self drawn

(2) Feijia Village

Feijia Village covers an area of 0.68 square kilometers. It has a permanent population of 342 and a floating population of 8,500 . Feijia Village is home to many Chinese and foreign artists. It is one of the top ten art districts in Beijing and deserves the name "Artist's village". Mananli community is located in the east side of Feijia Village. It is the public housing of farm units in the eastern suburbs. It is divided into two communities, covering an area of more than $200 \mathrm{mu}$, with a total of more than 2200 households and 6,795 people(figure 9,10). 


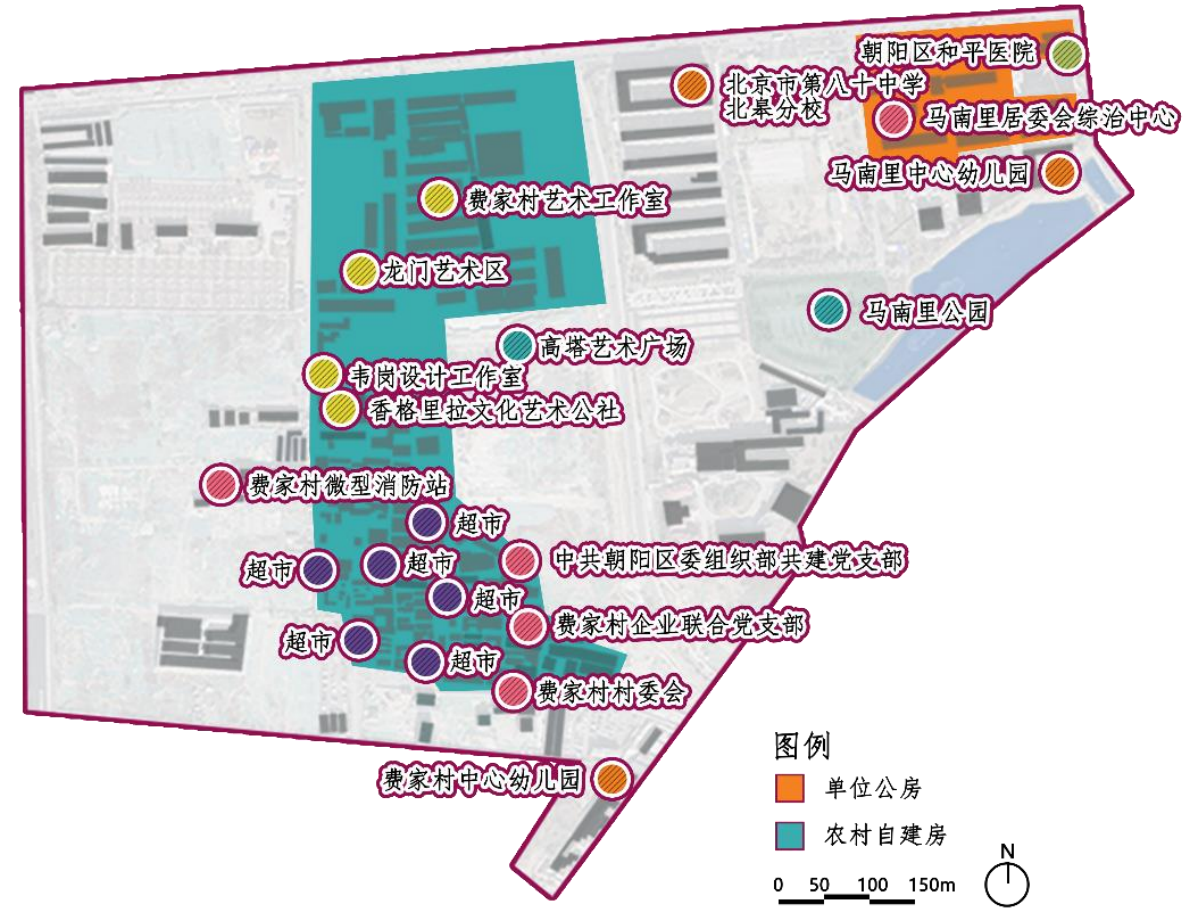

Figure 9. .Residential space differentiation and infrastructure distribution in Feijia Village

Source: self drawn
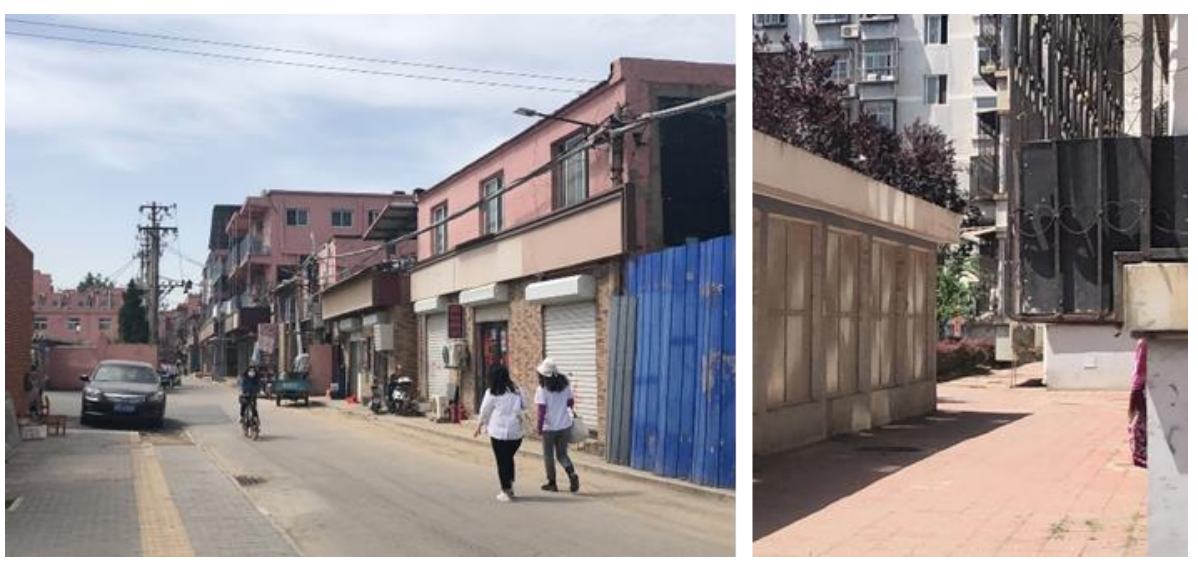

Figure 10. Real scene of Feijia Village

Source: self drawn

(3) Jingwang Community

Jingwang home is not only a directional resettlement project of Nangao Group in Cuigezhuang township, Chaoyang District, specially used for the project of peasants upstairs after the demolition of 15 old villages in Cuigezhuang township, but also part of the commercial housing. Jingwang Home is divided into seven districts with about 7,400 households(figure 11,12). 


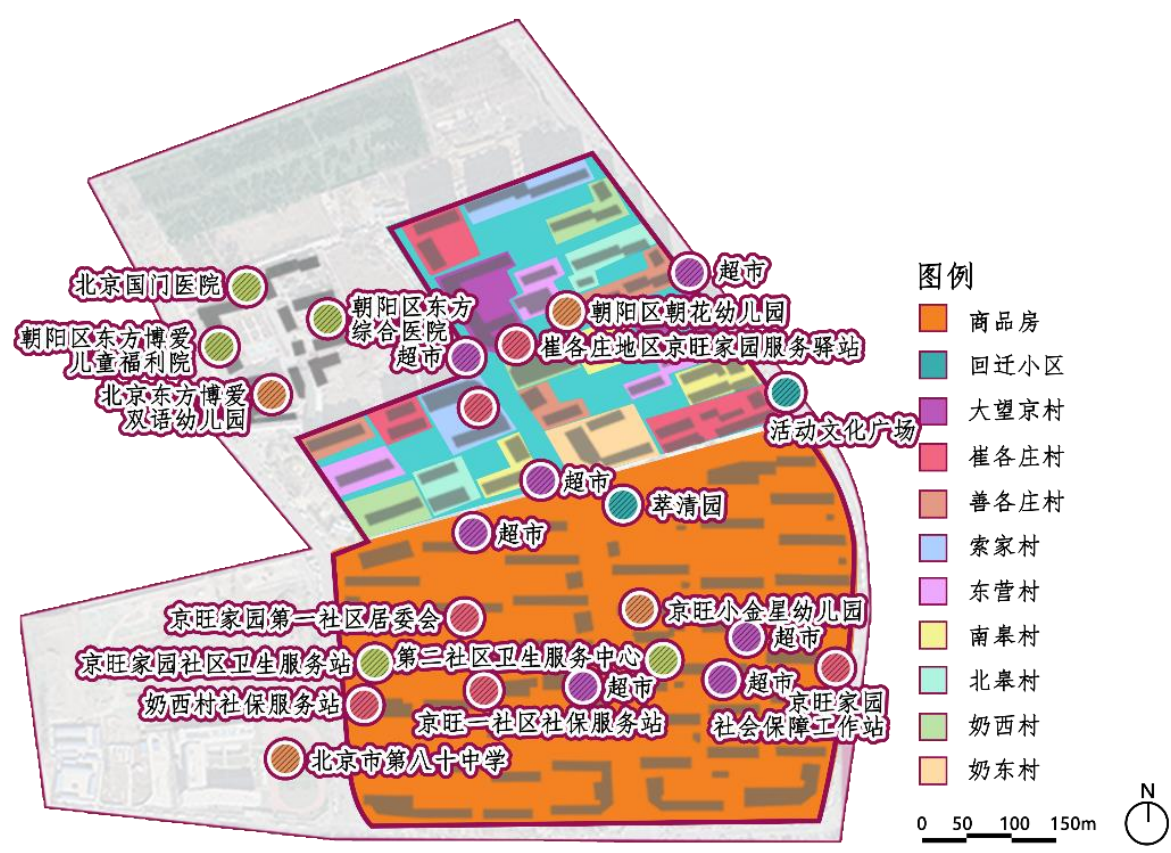

Figure 11. Residential space differentiation and infrastructure distribution in Jingwang community

Source: self drawn
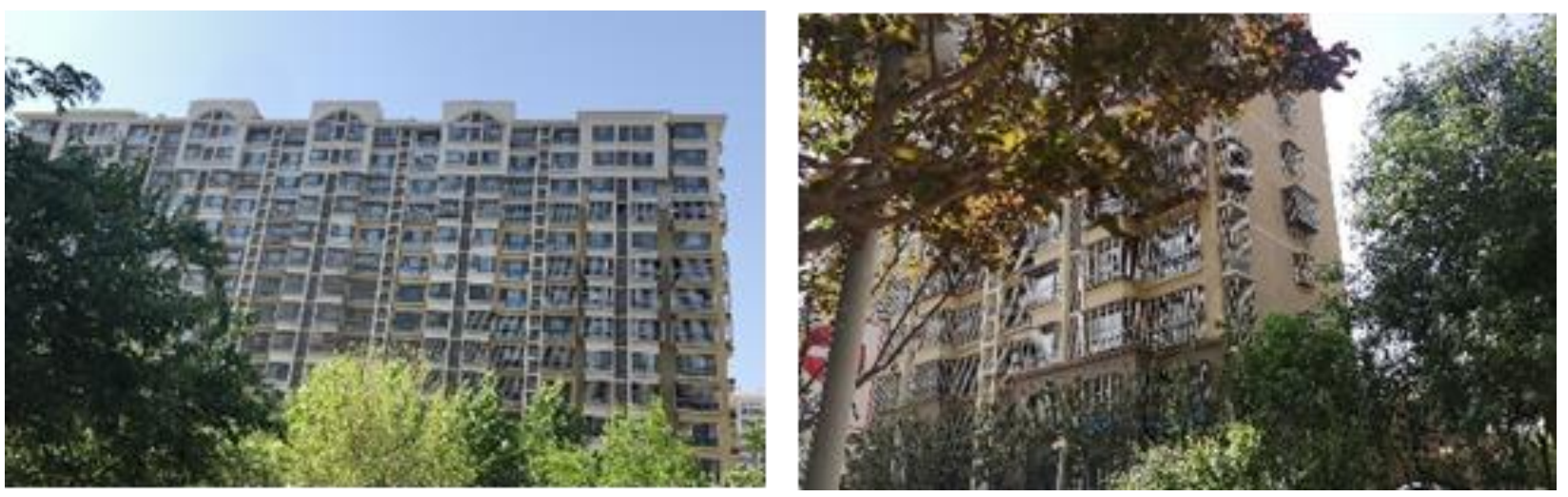

Figure 12. Real map of Jingwang community

Source: self drawn

\subsection{Status quo of residents' integration in typical communities}

Residential spatial differentiation is a normal phenomenon associated with urban development, and is not a problem in itself. However, serious residential spatial differentiation will lead to social isolation and social exclusion. Therefore, it is an issue that cannot be ignored to study the social integration of residents under residential spatial differentiation.

Based on this, this paper established two way green every dimension of social integration of the people in a typical area and the specific evaluation index system, for any area, fee home village (part contains Ma Nali community), analyzing the present situation and problems of Beijing prosperous community social integration, in order to investigate high degree of differentiation of residential space space community (village) residents of social integration, and summarizes characteristics of the various dimensions of social integration.

4.2.1 Selection of fusion factor indicators 
By sorting out and summarizing the social integration indicators in the existing literature and filling in the gaps, this paper mainly selects the corresponding indicators from the four aspects of economic work, social participation, social relations and psychology to construct the factor system of residents' social integration[31-39].(Table1)

Table 1 .Fusion factor index

\begin{tabular}{|c|c|c|}
\hline $\begin{array}{l}\text { Primary } \\
\text { index }\end{array}$ & secondary index & variable \\
\hline \multirow{7}{*}{$\begin{array}{l}\text { The basic } \\
\text { information }\end{array}$} & Gender & "male" =1, "female" =2 \\
\hline & Age & $\begin{array}{l}\text { "under } 18=1 ", \quad \text { "18 to } 30=2 ", \quad \text { " } 41 \text { to } 50=4 ", \text { "50 } \\
\text { to } 60=5 ", \quad \text { "61 years old and above = 6" }\end{array}$ \\
\hline & Household nature & $\begin{array}{l}\text { "agricultural household" =1, "non-agricultural } \\
\text { household" =2, "provincial agricultural household" } \\
=3, \quad \text { "provincial non-agricultural household" =4 }\end{array}$ \\
\hline & Marital status & $\begin{array}{l}\text { "Married" =1, "Unmarried" =2, "Divorced" =3, } \\
\text { "widowed" =4 }\end{array}$ \\
\hline & Education level & $\begin{array}{l}\text { "primary school and below" =1, "junior high school" } \\
=2 \text {, "senior high school (including technical } \\
\text { secondary school and technical school)" =3, "junior } \\
\text { college and above" =4, "Bachelor degree and } \\
\text { above" =5 }\end{array}$ \\
\hline & Income & $\begin{array}{l}\text { "less than } 2000 \text { yuan" =1, "2001-4000 yuan =2", } \\
\text { "4001-6000 yuan" =3, "6001-8000 yuan" =4, "above } \\
8000 \text { yuan" =5 }\end{array}$ \\
\hline & Professional & $\begin{array}{l}\text { "government departments at all levels, enterprises } \\
\text { and institutions, leaders of party and government } \\
\text { organs and public organizations" }=1 \text {, "" professional } \\
\text { and technical personnel }=2, " \text { the clerk (personnel } \\
\text { engaged in the work of general affairs) = } 3 \text {, } \\
\text { "business people" = 4, "the third industry, service } \\
\text { personnel" = } 5 \text {, "workers" }=6 \text {, "the laborers } \\
\text { engaged in agriculture, forestry and fisheries" = 7, } \\
\text { "students" = } 8 \text {, "Private business owner" }=9 \text {, } \\
\text { "unemployed" }=10 \text {, "retired" =11, "other" =12 }\end{array}$ \\
\hline & $\begin{array}{l}\text { Economic latitude work } \\
\text { stability(work in last two } \\
\text { years the number of times) }\end{array}$ & $\begin{array}{l}\text { "zero"=1, "1 to } 2 \text { times" = 2, = } 3 \text { "3-4 times", "four } \\
\text { to five times" = 4, "more than five times" = } 5\end{array}$ \\
\hline & Social security & $\begin{array}{l}\text { "no security" =1, "With commercial insurance" =2, } \\
\text { "with rural security" =3, "with urban insurance" =4 }\end{array}$ \\
\hline & $\begin{array}{l}\text { Distance between a job and } \\
\text { residence }\end{array}$ & $\begin{array}{l}\text { within } 1 \mathrm{~km}=1,1-5 \mathrm{~km}=2,5-10 \mathrm{~km}=3 \text {, and more } \\
\text { than } 10 \mathrm{~km}=4\end{array}$ \\
\hline
\end{tabular}




\begin{tabular}{|c|c|c|}
\hline \multirow[t]{4}{*}{$\begin{array}{l}\text { Social } \\
\text { Interaction } \\
\text { Dimensions }\end{array}$} & $\begin{array}{l}\text { Social interaction scale } \\
\text { (how many people do you } \\
\text { know in the community) }\end{array}$ & $\begin{array}{l}\text { " } 5 \text { or less" =1, "6-10" =2, "11-15" =3, "16-20" =4, " } \\
\text { more than } 20 "=5\end{array}$ \\
\hline & $\begin{array}{l}\text { Friendliness of community } \\
\text { members (How many } \\
\text { neighbors will help you } \\
\text { when you are in trouble or } \\
\text { borrow daily items) }\end{array}$ & $0=1,1-3=2,4-6=3,7-9=4$, and more than $10=5$ \\
\hline & $\begin{array}{l}\text { Neighborhood interaction } \\
\text { (how many times in a week } \\
\text { do you chat with other } \\
\text { residents in your } \\
\text { community?) }\end{array}$ & $\begin{array}{l}\text { "0" =1, "1-2" =2, "3-4" =3, "5-6" =4, "more than 6" } \\
=5\end{array}$ \\
\hline & $\begin{array}{l}\text { Neighborhood (How many } \\
\text { neighbors in your } \\
\text { community are close to } \\
\text { you) }\end{array}$ & $\begin{array}{l}5 \text { or less }=1,6 \text { to } 10=2,11 \text { to } 15=3,16 \text { to } 20=4,20 \\
\text { or more }=5\end{array}$ \\
\hline \multirow[t]{4}{*}{$\begin{array}{l}\text { Social } \\
\text { participation } \\
\text { Latitude }\end{array}$} & $\begin{array}{l}\text { Community participation } \\
\text { (number of activities you } \\
\text { participate in in a year) }\end{array}$ & \multirow[t]{4}{*}{ "0" =1, "1-2" =2, "3-4" =3, "5-6=4," more than 6 "=5 } \\
\hline & $\begin{array}{l}\text { Participation in } \\
\text { Government Activities } \\
\text { (number of activities you } \\
\text { participated in in a year) }\end{array}$ & \\
\hline & $\begin{array}{l}\text { Participation in activities of } \\
\text { social organizations } \\
\text { (number of activities you } \\
\text { participated in in a year) }\end{array}$ & \\
\hline & $\begin{array}{l}\text { Participation in Private } \\
\text { (artist) activities (number } \\
\text { of activities you } \\
\text { participated in in a year) }\end{array}$ & \\
\hline \multirow[t]{3}{*}{$\begin{array}{l}\text { Psychological } \\
\text { dimensions }\end{array}$} & $\begin{array}{l}\text { Psychological dimensions } \\
\text { of self-identification (do } \\
\text { you see yourself as part of } \\
\text { the community) }\end{array}$ & \multirow[t]{3}{*}{$\begin{array}{l}\text { "Strongly disagree" =1, "disagree" =2, "both agree } \\
\text { and disagree" =3, "Agree" =4, "strongly agree" =5 }\end{array}$} \\
\hline & $\begin{array}{l}\text { Identification with others } \\
\text { (do you consider other } \\
\text { outsiders to be part of the } \\
\text { community) }\end{array}$ & \\
\hline & $\begin{array}{l}\text { Adaptability (community } \\
\text { feels like home) }\end{array}$ & \\
\hline
\end{tabular}




\begin{tabular}{|l|l|l|}
\hline & $\begin{array}{l}\text { Satisfaction (whether your } \\
\text { life meets your needs) }\end{array}$ & $\begin{array}{l}\text { "No" =1, "not enough" =2, "almost up to" =3, } \\
\text { "already up to" =4, "more than your needs" =5 }\end{array}$ \\
\hline $\begin{array}{l}\text { Belonging (willingness to } \\
\text { settle down in the long } \\
\text { term) }\end{array}$ & $\begin{array}{l}\text { "very unwilling" =1, "unwilling" =2, "both willing } \\
\text { and unwilling" =3, "willing" =4, "very willing" =5 }\end{array}$ \\
\hline Source: self drawn &
\end{tabular}

\subsubsection{Degree of social integration of different residential space types}

STATA software was used for testing, in which the KOM value reached 0.799 , and the KOM test passed. The concomitant probability was 0.000 , less than 0.05 , indicating that the Bartlett sphericity test had passed and was very suitable for factor analysis(Table2).

Table 2. KOM and Bartlett tests

\begin{tabular}{|l|l|l|}
\hline \multicolumn{2}{|l|}{ KMO and Bartlett tests } & 0.799 \\
\hline KMO sampling suitability quantity. & $\begin{array}{l}\text { Bartlett's sphericity test } \\
\text { approximate chi-square }\end{array}$ & 2547.357 \\
\hline $\begin{array}{l}\text { Bartlett's sphericity test approximate test } \\
\text { chi-square }\end{array}$ & $\begin{array}{l}\text { Bartlett's sphericity } \\
\text { approximate chi-square }\end{array}$ \\
\hline
\end{tabular}

Source: self drawn

Dimensions according to the variance contribution rate and cumulative variance contribution rate, calculate the linear weighted value of the principal component, construct the comprehensive evaluation function, get comprehensive coefficient in the model, it is the weight of each dimension indexes in the social integration, the weight of the economic dimension is 0.21 , the weight of social dimension is 0.12 , the weight of social participation dimension is 0.17 , The weight of the cultural dimension is 0.09 , the weight of the psychological dimension is 0.15 , and the weight of the residential dimension is 0.27 . The equal weight method is used to determine the weight of indicators in each dimension, and the specific weight is shown in the table(Table3):

Table 3. Index weights of various dimensions of social integration (coefficients in the comprehensive model)

\begin{tabular}{|l|l|l|}
\hline The coefficient & Zscore(job stability) & 0.01038607 \\
$\begin{array}{l}\text { Zscore in the } \\
\text { comprehensive } \\
\text { score model }\end{array}$ & Zscore(Social Security) & 0.136350679 \\
\cline { 2 - 3 } & Zscore(Residential distance) & -0.022055929 \\
\cline { 2 - 3 } & $\begin{array}{l}\text { Zscore(Social interaction } \\
\text { scale) }\end{array}$ & 0.143897413 \\
\cline { 2 - 3 } & $\begin{array}{l}\text { Zscore(Community member } \\
\text { friendliness) }\end{array}$ & 0.158090453 \\
\cline { 2 - 3 } & \begin{tabular}{l} 
Zscore(Neighborhood) \\
\cline { 2 - 3 }
\end{tabular} & 0.137443833 \\
Zscore(Neighborhood & 0.157448904 \\
\hline
\end{tabular}




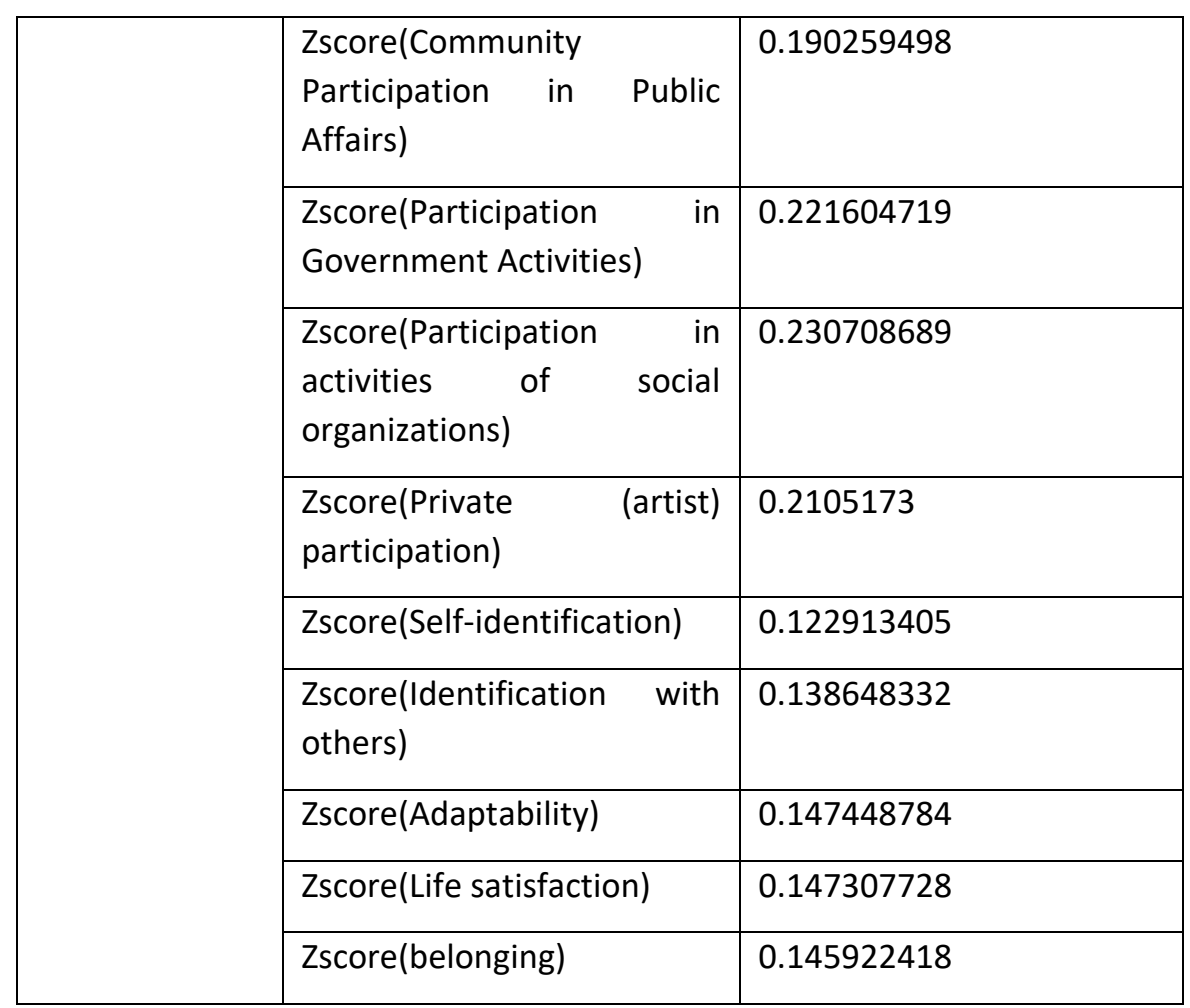

Source: self drawn

According to the weights of indicators and dimensions in the measurement system of social integration, the social integration in each dimension of social integration is calculated for the samples.

It is found that there is little difference in social integration degree between Feijia village and Hegezhuang village from the perspective of social integration degree of three typical communities in Cuigezhuang township. From the perspective of social integration dimensions, the scores of social integration dimensions of the three typical communities in Cuigezhuang township basically show the descending situation of social interaction dimension integration, psychological dimension integration, social participation dimension integration, economic work dimension integration. It shows that the integration degree of social interaction latitude, psychological dimension and social participation latitude is high, but the integration degree of economic work latitude is low.

From the perspective of different residential space types in the same community (village), the degree of social integration of residents is significantly different. "Unit compound" and "returning residential area" have the highest degree of social integration, indicating that the residential space differentiation formed mainly by centralized resettlement will promote social participation and communication. Residents living in the "commercial housing area of relatively low degree of social integration, the housing commercialization degree are higher, good living environment, hardware of its social integration has a natural advantage, but since it is a large residential community, large population base, diversification, and collective participation in community activities is not high, so low social integration; "Self-built houses in rural areas" is the lowest, which is also verified by the analysis results of housing types and mean values of social integration. (Table4)

Table 4. Social integration of different residential space types in three typical communities (villages)

\begin{tabular}{|c|c|c|c|c|c|}
\hline $\begin{array}{l}\text { Average } \\
\text { item of line } \\
\text { label }\end{array}$ & $\begin{array}{l}\text { Average value: } \\
\text { degree } \\
\text { integration of }\end{array}$ & $\begin{array}{l}\text { Average value :F1 } \\
\text { social } \\
\text { participation }\end{array}$ & $\begin{array}{l}\text { Average } \\
\text { value :F2 } \\
\text { psychological }\end{array}$ & $\begin{array}{l}\text { Average } \\
\text { value :F3 } \\
\text { Social } \\
\text { integration }\end{array}$ & $\begin{array}{l}\text { Average } \\
\text { value:F4 } \\
\text { economic }\end{array}$ \\
\hline
\end{tabular}


Yuting Li.

Main Title Residential space differentiation and

social integration of typical settlements in the typical area of Beijing second Green Belt

\begin{tabular}{|c|c|c|c|c|c|}
\hline & $\begin{array}{l}\text { social } \\
\text { participation }\end{array}$ & $\begin{array}{l}\text { dimension } \\
\text { integration }\end{array}$ & $\begin{array}{l}\text { dimension } \\
\text { fusion }\end{array}$ & & $\begin{array}{l}\text { (working) } \\
\text { latitude fusion }\end{array}$ \\
\hline $\begin{array}{l}\text { Feijia Village } \\
\text { total }\end{array}$ & 6.142458963 & 4.208765561 & 9.311840506 & 10.34346153 & 1.220988807 \\
\hline $\begin{array}{l}\text { Feijia Village } \\
\text { (rural self- } \\
\text { built } \\
\text { Housing) }\end{array}$ & 5.486060082 & 3.296549331 & 8.717007942 & 9.978232636 & 1.063666231 \\
\hline $\begin{array}{l}\text { Manang Li } \\
\text { Community } \\
\text { (Unit } \\
\text { compound) }\end{array}$ & 6.210467512 & 4.204699241 & 9.608861026 & 10.22010414 & 1.370375432 \\
\hline $\begin{array}{l}\mathrm{He} \\
\text { Gezhuang } \\
\text { village }\end{array}$ & 6.074450414 & 4.21283188 & 9.014819985 & 10.46681892 & 1.071602182 \\
\hline $\begin{array}{l}\text { Hegezhuang } \\
\text { Village } \\
\text { (rural self- } \\
\text { built house) }\end{array}$ & 5.563883848 & 3.964850298 & 7.996252181 & 9.386902034 & 1.394313692 \\
\hline $\begin{array}{l}\text { Hegezhuang } \\
\text { Residential } \\
\text { area (return } \\
\text { residential } \\
\text { area) }\end{array}$ & 7.010489119 & 4.667464782 & 10.88219429 & 12.44666654 & 0.479964415 \\
\hline $\begin{array}{l}\text { Jingwang } \\
\text { Homeland } \\
\text { Community } \\
\text { (commercia } \\
\text { I housing) }\end{array}$ & 5.676335936 & 3.36135052 & 9.467009518 & 9.418870579 & 1.65180858 \\
\hline
\end{tabular}

Source: self drawn

\section{Factors influencing the social integration of residents in four types of residential space}

Do residential elements under different residential space types have a significant impact on social integration, and is the impact direct or caused by other factors? Based on the above empirical research, quantitative analysis and qualitative analysis were combined to explore the relationship between the residential elements of the four types of residential space and the overall degree of social integration of the corresponding residents, as well as the mechanism of the residential elements of the four types of residential space on the social integration of different latitudes.

The factors of living space are measured by 15 indicators: housing type, housing location and per capita housing area. With time and the number of the per capita living area, the rent price, cohabitation, living environment, living surrounding facilities such as live factor as the independent variables, overall social alignment factor, economic factor (work) latitude, social participation latitude latitude latitude factor, 
social factor and psychological factor as the dependent variable, using STATA do stepwise regression four regression equation is obtained finally. (Table5)

Table 5. Residential differentiation indicators

\begin{tabular}{|c|c|c|}
\hline \multirow{7}{*}{$\begin{array}{c}\text { Residen } \\
\text { tial } \\
\text { differen } \\
\text { tiation } \\
\text { index }\end{array}$} & Live time & $\begin{array}{l}\text { " under } 1 \text { year = 1", "two to five years" = 2, = } 3 \\
\text { "6-10 years", "11-15 years" = 4, "16 years = 5", } \\
\text { "lived" = } 6\end{array}$ \\
\hline & Reason for residence & $\begin{array}{l}\text { "Work" }=1, \text { "a child to school" }=2, \text { "traffic } \\
\text { convenience" }=3, \text { "convenient facilities" }=4 \text {, } \\
\text { "ancestors living in this" = } 5, \text { "follow your lover } \\
\text { married" = } 6\end{array}$ \\
\hline & Per capita living area & $\begin{array}{l}\text { "10 square meters or less" }=1, " 11-20 \text { square } \\
\text { meters" }=2, " 21-30 \text { square meters" }=3, " 31-40 \\
\text { square meters" }=4 \text {, and "over } 40 \text { square meters" } \\
=5\end{array}$ \\
\hline & The rent price & $\begin{array}{l}0 \text { yuan }=6 \text {, less than } 1,000 \text { yuan }=5,1,000-1,500 \\
\text { yuan }=4,1,500-2,500 \text { yuan }=3,2,500-5,000 \text { yuan } \\
=2 \text {, and more than } 5,000 \text { yuan }=1\end{array}$ \\
\hline & The number of cohabitation & $\begin{array}{l}\text { "Residents use the toilet inside the community" } \\
=1 \text {, "public hutch is used inside the building" }=2 \text {, } \\
\text { "the building has independent hutch and } \\
\text { bathroom, but the space is very narrow" =3, "the } \\
\text { building has independent hutch and bathroom, } \\
\text { the space is more satisfied" =4, "the building has } \\
\text { an independent hutch and bathroom with larger } \\
\text { area and well-equipped facilities" =5 }\end{array}$ \\
\hline & Quality conditions of residential housing & $\begin{array}{l}\text { "Residents use the toilet inside the community" } \\
=1 \text {, "public hutch is used inside the building" }=2 \text {, } \\
\text { "the building has independent hutch and } \\
\text { bathroom, but the space is very narrow" =3, "the } \\
\text { building has independent hutch and bathroom, } \\
\text { the space is more satisfied" =4, "the building has } \\
\text { an independent hutch and bathroom with larger } \\
\text { area and well-equipped facilities" = }\end{array}$ \\
\hline & Sanitary conditions & $\begin{array}{l}\text { "Garbage everywhere on the ground" }=1 \text {, } \\
\text { "garbage often on the ground" }=2 \text {, "garbage } \\
\text { occasionally on the ground" }=3 \text {, "almost no } \\
\text { garbage on the ground" }=4 \text {, "sanitary and }\end{array}$ \\
\hline
\end{tabular}




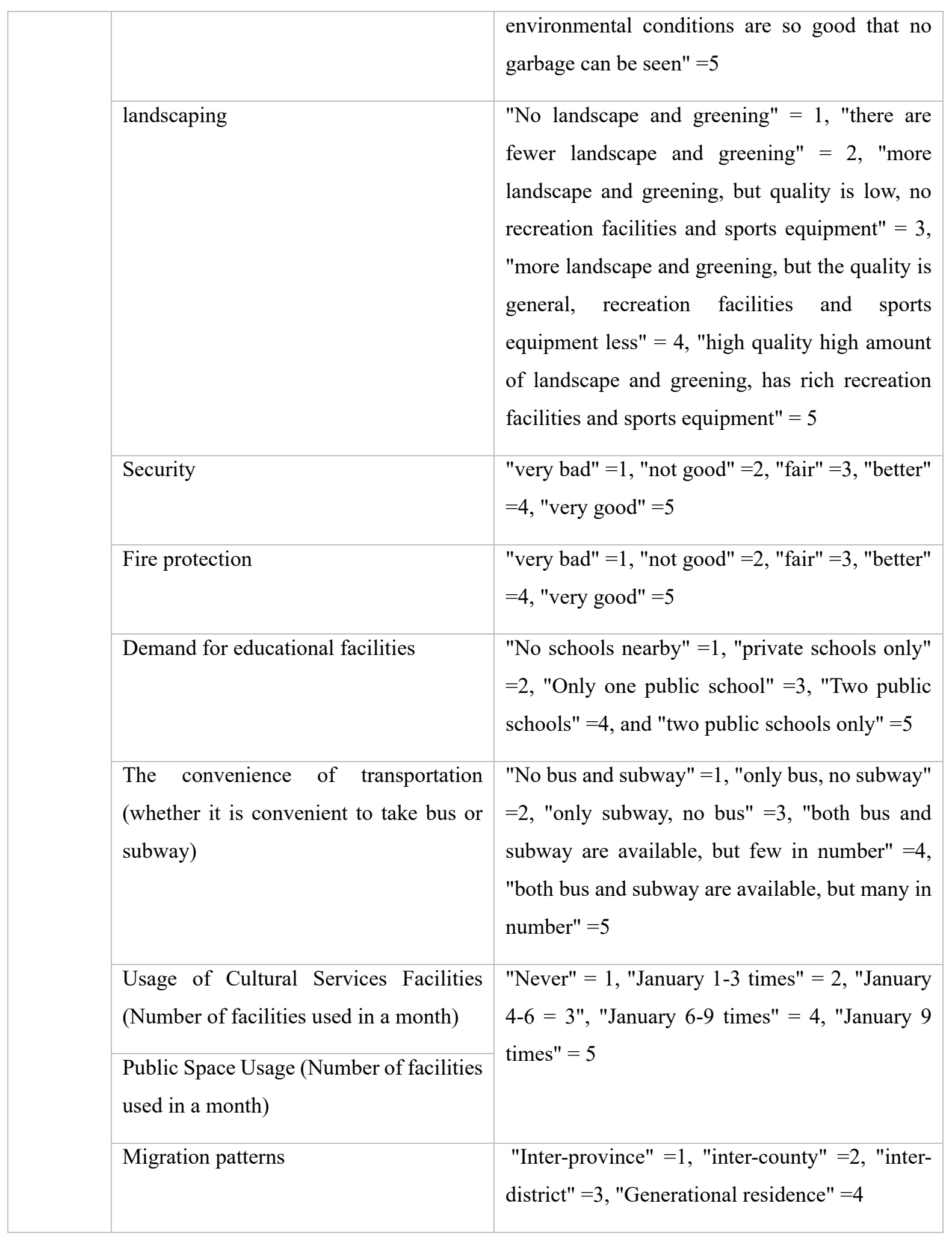

Source: self drawn

\subsection{Impacts of residential elements on social integration under the four types of}

residential space

(1) The impact of residential elements of rural self-built houses on social integration 
In the process of social integration of rural self-built migrant population, the factors influencing the overall degree of social integration in descending order are: public security, utilization rate of cultural service facilities, rent price, per capita living area, living reasons, and the significant level is $P<0.001$. Four variables, including the number of people living together, housing quality, fire protection and migration pattern, were eliminated.

Among the residential factors, sanitary environment has the greatest influence on the overall social integration of rural self-built migrant population. Among them, F1 social interaction integration, F2 psychological integration and F3 social participation integration of the investigated group had a negative impact, and the correlation was strong $(P<0.001)$, with regression coefficients of $-0.688,-0.539$ and -1.051 , respectively). That shows the lives in rural health conditions good since foreign residents than to live for a house in rural poor sanitation condition of the construction of social participation, social interaction, alignment, lower identity is also low, according to the survey, the live in a better quality of living environment of rural construction are some artists or foreigners, they often closed-door creation, There is little communication with the outside world.

Public security mainly plays a significant positive role in promoting social integration (regression coefficient $0.542, \mathrm{P}<0.001)$, ranking the first among all factors affecting psychological integration. According to the survey, public security seriously affects the migrant population's identity, adaptability and life satisfaction.

The utilization rate of cultural service facilities played a significant positive role in promoting social integration (regression coefficient was $0.308, \mathrm{P}<0.001$ ). Among them, it has a positive impact on the social interaction integration and social participation integration of the investigated groups, indicating that residents with more frequent use of cultural service facilities have higher social interaction and social participation behavior. However, it has a negative impact on the latitude of economic work, indicating that residents with more frequent use of cultural service facilities have a closer distance to work and a more stable job than residents with less frequent use of cultural service facilities.

Rent price also plays a significant positive role in promoting social integration (regression coefficient is $0.208, P<0.001)$, that is to say, the higher the rent, the more advantageous the location and living environment, and the higher the degree of social integration. Among them, it has a positive impact on the psychological integration and social participation integration of the investigated groups, indicating that residents living in rural self-built houses with high rent have higher life satisfaction, higher self-identity and other people's identity, and generally high participation in community activities. However, it has a negative impact on the economic work latitude, which indicates that the residents living in the rural self-built houses with higher rent have a closer distance to work and a more stable job.

Housing area per capita and reasons for living had significant influence on social integration (regression coefficient was $0.168,0.196$. $\mathrm{P}<0.001$ ). The per capita housing area has a positive impact on psychological integration, indicating that the larger the per capita housing area, the higher the sense of identity and life satisfaction. Residence reasons also affect the psychological integration and social participation integration of residents.

In addition, residence time also has a significant positive impact on psychological integration. The demand for educational facilities will have a significant positive impact on social interaction integration. (Table6)

Table 6. Multiple regression model of residential space elements and social integration of rural self-built houses

\begin{tabular}{|l|l|l|l|l|l|}
\hline & 1 & 2 & 3 & 4 & 5 \\
\hline
\end{tabular}




\begin{tabular}{|c|c|c|c|c|c|}
\hline & $\begin{array}{l}\text { Social } \\
\text { integration }\end{array}$ & $\begin{array}{l}\text { F1 Social } \\
\text { interaction } \\
\text { integration }\end{array}$ & $\begin{array}{l}\text { F2 } \\
\text { psychological } \\
\text { integration }\end{array}$ & $\begin{array}{l}\text { F3 Social } \\
\text { participation } \\
\text { integration }\end{array}$ & $\begin{array}{l}\text { F4 Economic } \\
\text { work } \\
\text { integration }\end{array}$ \\
\hline Living time & 0.0999* & 0.0163 & $0.360 * * *$ & 0.14 & $-0.173 * * *$ \\
\hline $\begin{array}{l}\text { Per capita } \\
\text { living area }\end{array}$ & $0.196 * * *$ & $0.166 * *$ & $0.400 * * *$ & 0.131 & -0.0262 \\
\hline $\begin{array}{l}\text { Residence } \\
\text { reason }\end{array}$ & $0.168 * * *$ & $0.135^{* *}$ & $0.285^{* * *}$ & $0.283^{*} * *$ & $-0.115^{* *}$ \\
\hline $\begin{array}{l}\text { Housing } \\
\text { Environment } \\
\text { and } \\
\text { Conditions }\end{array}$ & -0.0678 & 0.0287 & -0.183 & $-0.371 * *$ & $0.221 * * *$ \\
\hline $\begin{array}{l}\text { Health } \\
\text { conditions }\end{array}$ & $-0.608 * * *$ & $-0.688 * * *$ & $-0.539 * * *$ & $-1.051 * * *$ & $0.214^{*}$ \\
\hline $\begin{array}{l}\text { Landscape } \\
\text { greening }\end{array}$ & -0.179 & -0.153 & $-0.486 * *$ & 0.121 & -0.0634 \\
\hline Public security & $0.542 * * *$ & $0.469 * * *$ & $0.753 * * *$ & $1.024 * * *$ & $-0.305^{* *}$ \\
\hline $\begin{array}{l}\text { Cultural } \\
\text { service } \\
\text { facilities use }\end{array}$ & $0.308 * * *$ & $0.438 * * *$ & 0.139 & $0.554 * * *$ & $-0.219 * * *$ \\
\hline $\begin{array}{l}\text { Public space } \\
\text { utilization rate }\end{array}$ & 0.0548 & 0.0428 & 0.107 & 0.0906 & -0.0602 \\
\hline $\begin{array}{l}\text { Demand for } \\
\text { educational } \\
\text { facilities }\end{array}$ & $-0.195 * *$ & $0.268^{* * *}$ & -0.153 & $-0.279 *$ & $0.139 *$ \\
\hline $\begin{array}{l}\text { Ease of } \\
\text { transportation }\end{array}$ & $0.135^{*}$ & 0.106 & 0.184 & $0.293^{*}$ & -0.0832 \\
\hline The rent price & $0.208^{* * *}$ & 0.095 & $0.436 * * *$ & $0.422 * * *$ & $-0.127^{* * *}$ \\
\hline \multicolumn{6}{|c|}{ t statistics in parentheses } \\
\hline$* \mathrm{p}<0$ & 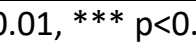 & & & & \\
\hline
\end{tabular}

Source: self drawn

(2) The impact of residential elements of returning communities on social integration

For the relocating community, the factors influencing the overall degree of social integration were as follows: landscape greening, public security, living time and living reasons, with a significant level of $P<$ 0.001. Other variables were eliminated.

Among the residential factors, landscape greening has the greatest influence on the overall social integration of the migrant population. Landscape greening mainly played a significant positive role in promoting social integration (regression coefficient was $0.490, P<0.001$ ), ranking the first among all factors affecting social participation and integration, and promoting social interaction and psychological integration. According to the survey, landscape greening has a serious impact on the recognition degree, 
adaptability and life satisfaction of the migrant population. In addition, the landscape greening of the residential area is better, which provides a platform for foreign residents to carry out social communication.

Public security mainly plays a significant positive role in promoting social integration (regression coefficient $0.542, \mathrm{P}<0.001$ ), and has a negative impact on social interaction integration and psychological integration. According to the survey, public security affects migrants' identity, adaptability, life satisfaction and relationship with others.

Time of residence and reason of residence also have a significant positive impact on social integration. Among them, residence time has a positive impact on the psychological integration of the investigated groups, and residence reason has a positive impact on psychological integration and social participation integration. The migration pattern has a significant positive impact on economic work, indicating that the people who have moved from other provinces to live here are more unstable in work and farther away from work and residence.

However, the housing environment and conditions have a negative impact on the social integration of migrants. Among them, F1 social interaction integration and F4 social participation integration of the investigated groups had a negative impact, with strong correlation $(P<0.001$, regression coefficients were -0.635 and -0.910 , respectively). According to the survey, the people who live in the residential areas with better living environment quality are the people with higher income. They basically do not participate in the local community public activities, such as square dancing, community discussion, etc., and make small friends with average neighborhood relations. In addition, the rent price has a negative impact on social integration, and the sanitary environment has a negative impact on the psychological dimension, indicating that high-income migrants living here are not conducive to integration into this community. The migration pattern has a negative impact on social participation, indicating that the degree of social participation integration of residents who migrate from other provinces is lower than that of residents who migrate across regions. (Table7)

Table 7. The impact of residential space elements of returning residential areas on social integration

\begin{tabular}{|l|l|l|l|l|l|}
\hline & 1 & 2 & 3 & 4 & 5 \\
\hline & $\begin{array}{l}\text { Social } \\
\text { integration }\end{array}$ & $\begin{array}{l}\text { F1 Social } \\
\text { interaction } \\
\text { integration }\end{array}$ & $\begin{array}{l}\text { F2 } \\
\text { psychological } \\
\text { integration }\end{array}$ & $\begin{array}{l}\text { F3 Social } \\
\text { participation } \\
\text { integration }\end{array}$ & $\begin{array}{l}\text { F4 Economic } \\
\text { work } \\
\text { integration }\end{array}$ \\
\hline Household property & $0.0997^{*}$ & 0.0143 & $0.311^{* * *}$ & $0.217^{* *}$ & $-0.174^{* * *}$ \\
\hline Residence time & $0.203^{* * *}$ & $0.174^{* *}$ & $0.412^{* * *}$ & 0.122 & -0.00963 \\
\hline Residence reason & $0.166^{* * *}$ & $0.122^{* *}$ & $0.308^{* * *}$ & $0.273^{* * *}$ & $-0.110^{* *}$ \\
\hline Migration mode & -0.078 & 0.0186 & -0.169 & $-0.410^{* * *}$ & $0.199^{* * *}$ \\
\hline $\begin{array}{l}\text { Residential housing } \\
\text { environment and } \\
\text { conditions }\end{array}$ & $-0.554^{* * *}$ & $-0.635^{* * *}$ & $-0.495^{* *}$ & $-0.910^{* * *}$ & 0.166 \\
\hline $\begin{array}{l}\text { Sanitary } \\
\text { environmental } \\
\text { conditions }\end{array}$ & -0.186 & -0.144 & $-0.526^{* * *}$ & 0.108 & -0.0543 \\
\hline Landscape greening & $0.490^{* * *}$ & $0.406^{* * *}$ & $0.736^{* * *}$ & $0.889^{* * *}$ & $-0.266^{* *}$ \\
\hline Public security & $0.290^{* * *}$ & $0.422^{* * *}$ & 0.137 & $0.475^{* * *}$ & $-0.195^{* * *}$ \\
\hline
\end{tabular}




\begin{tabular}{|l|l|l|l|l|l|}
\hline Traffic convenience & 0.061 & 0.0488 & 0.112 & 0.102 & -0.0586 \\
\hline t statistics in parentheses \\
\hline$* p<0.05, * * p<0.01, * * * p<0.001$ \\
\hline
\end{tabular}

Source: self drawn

(3) The impact of residential elements of unit compound on social integration

In the process of social integration of the migrant population in the unit compound, the factors that have an effect on the overall degree of social integration are as follows: cultural service facilities, rent price, public security and sanitary environment, with a significant level of $P<0.001$. Other variables were eliminated.

The utilization rate of cultural service facilities has the greatest impact on the overall social integration. It ranked first among all factors affecting social participation and integration and social interaction, indicating that the higher the frequency of using cultural service facilities, the higher the adaptability to the Mananli community, the higher the identity of others and self, the higher the degree of life satisfaction, and the higher the degree of active participation in community activities. Rent prices also have a greater impact on social integration. Among them, there is a positive impact on social interaction integration, indicating that in the unit courtyard, residents who pay higher rent have better neighborhood relations and larger scale of friends. Public security plays a positive role in promoting social integration, especially in social interaction integration. The reason and duration of residence also play a significant role in promoting psychological integration. Health environment has a negative effect on social integration, among which, it has a negative effect on social interaction integration. (Table8)

Table 8. Regression model of residential space elements and social integration of unit compound

\begin{tabular}{|l|l|l|l|l|l|}
\hline & 1 & 2 & 3 & 4 & 5 \\
\hline & $\begin{array}{l}\text { Social } \\
\text { integration }\end{array}$ & $\begin{array}{l}\text { F1 Social } \\
\text { interaction } \\
\text { integration }\end{array}$ & $\begin{array}{l}\text { F2 } \\
\text { psychological } \\
\text { integration }\end{array}$ & $\begin{array}{l}\text { F3 Social } \\
\text { participation } \\
\text { integration }\end{array}$ & $\begin{array}{l}\text { F4 } \\
\text { Economic } \\
\text { work } \\
\text { integration }\end{array}$ \\
\hline Living time & $0.333^{*}$ & 0.289 & $0.830^{* * *}$ & 0.253 & $-0.435^{* * *}$ \\
\hline Per capita living area & 0.151 & 0.307 & -0.00594 & 0.0907 & -0.0678 \\
\hline Residence reason & 0.123 & -0.0778 & $0.393^{* * *}$ & $0.461^{* *}$ & -0.117 \\
\hline $\begin{array}{l}\text { Housing Environment } \\
\text { and Conditions }\end{array}$ & 0.0546 & 0.22 & -0.138 & -0.289 & $0.286^{* *}$ \\
\hline Health conditions & $-0.794^{* * *}$ & $-0.897^{* * *}$ & $-0.762^{*}$ & $-1.277^{* *}$ & 0.253 \\
\hline Landscape greening & -0.384 & -0.279 & $-0.843^{* *}$ & -0.298 & 0.0473 \\
\hline Public security service & $0.793^{* *}$ & $1.005^{* * *}$ & 0.525 & $1.374^{* *}$ & -0.345 \\
\hline $\begin{array}{l}\text { Cultural } \\
\text { facilities use }\end{array}$ & $0.341^{* * *}$ & $0.501^{* * *}$ & 0.103 & $0.678^{* * *}$ & $-0.298^{* * *}$ \\
\hline $\begin{array}{l}\text { Public } \\
\text { utilization rate }\end{array}$ & -0.0604 & -0.193 & 0.0685 & 0.0815 & 0.00522 \\
\hline $\begin{array}{l}\text { Demand for } \\
\text { educational facilities }\end{array}$ & -0.19 & -0.12 & $-0.428^{*}$ & -0.251 & 0.122 \\
\hline
\end{tabular}




\begin{tabular}{|l|l|l|l|l|l|}
\hline $\begin{array}{l}\text { Ease of } \\
\text { transportation }\end{array}$ & $0.300^{*}$ & $0.364^{*}$ & 0.265 & $0.455^{*}$ & -0.112 \\
\hline The rent price statistics in & $0.301^{* * *}$ & $0.389 * * *$ & $0.283^{* *}$ & $0.402^{* *}$ & $-0.174^{* *}$ \\
\hline $\begin{array}{l}\mathrm{t} \\
\text { parentheses }\end{array}$ & & & & \\
\hline $\begin{array}{l}* * 0.05, * * \mathrm{p}<0.01, \\
\mathrm{p}<0.001\end{array}$ & & & & & \\
\hline
\end{tabular}

Source: self drawn

(4) The impact of residential elements of residential areas on social integration

In the process of the social integration of the migrant population of commercial housing, the factor that plays an important role in the overall degree of social integration is the public security factor, with a significant level of $\mathrm{P}<0.001$.

Among them, public security factors have a positive effect on psychological integration and social participation integration, indicating that the better public security, the higher degree of recognition of Jingwang community residents, the stronger adaptability, and more participation in community affairs.

Health environment has a negative effect on social integration, among which, it has a negative effect on F1 social interaction dimension integration, F2 psychological dimension integration and F3 social relationship integration, indicating that living in communities with better health environment has a lower degree of social interaction and social participation integration. According to the survey, The people who live in the residential areas with better living environment quality are the people with higher income. They basically do not participate in the local community public activities, such as square dancing and community discussion, etc., and make small friends with average neighborhood relations. However, it has a positive effect on economic and work integration, indicating that the residents living in the living space with better sanitary environment have more adequate social security. (Table9)

Table 9. Impacts of residential space elements of commodity + returning residential areas on social integration

\begin{tabular}{|l|l|l|l|l|l|}
\hline & 1 & 2 & 3 & 4 & 5 \\
\hline & $\begin{array}{l}\text { Social } \\
\text { integration }\end{array}$ & $\begin{array}{l}\text { F1 Social } \\
\text { interaction } \\
\text { integration }\end{array}$ & $\begin{array}{l}\text { F2 } \\
\text { psychological } \\
\text { integration }\end{array}$ & $\begin{array}{l}\text { F3 } \\
\text { participation } \\
\text { integration }\end{array}$ & $\begin{array}{l}\text { F4 Economic } \\
\text { integration }\end{array}$ \\
\hline Living time & 0.0679 & 0.0169 & $0.425^{*}$ & -0.071 & $-0.289^{*}$ \\
\hline Per capita living area & 0.226 & $0.312^{*}$ & 0.222 & 0.209 & -0.0919 \\
\hline Residence reason & 0.0806 & 0.0811 & 0.224 & 0.0399 & $-0.171^{*}$ \\
\hline $\begin{array}{l}\text { Housing } \\
\text { Environment }\end{array}$ & -0.116 & 0.156 & -0.209 & $-1.214^{* *}$ & $0.548^{* *}$ \\
\hline $\begin{array}{l}\text { Health conditions } \\
\text { Landions }\end{array}$ & $-1.247^{* * *}$ & $-1.097^{* * *}$ & $-1.820^{* * *}$ & $-2.308^{* * *}$ & $0.894^{* * *}$ \\
\hline $\begin{array}{l}\text { Landscape greening } \\
\text { facilities use }\end{array}$ & 0.305 & 0.263 & 0.215 & $1.339^{* *}$ & $-0.828^{* *}$ \\
\hline $\begin{array}{l}\text { Public security } \\
\text { Cultural }\end{array}$ & $0.085^{* * *}$ & $0.663^{*}$ & $1.762^{* * *}$ & $2.370^{* * *}$ & $-0.491^{*}$ \\
\hline
\end{tabular}




\begin{tabular}{|c|c|c|c|c|c|}
\hline $\begin{array}{l}\text { Public space } \\
\text { utilization rate }\end{array}$ & 0.0805 & -0.00865 & 0.191 & 0.0483 & $0.256^{* *}$ \\
\hline $\begin{array}{lr}\text { Demand for } & \text { for } \\
\text { educational facilities }\end{array}$ & -0.0804 & -0.141 & -0.234 & 0.332 & -0.0984 \\
\hline $\begin{array}{l}\text { Ease of } \\
\text { transportation }\end{array}$ & -0.185 & -0.248 & -0.233 & -0.229 & $0.236^{*}$ \\
\hline The rent price & -0.0262 & $-0.250 *$ & 0.274 & $0.415^{*}$ & $-0.385 * * *$ \\
\hline \multicolumn{6}{|c|}{ t statistics in parentheses } \\
\hline
\end{tabular}

Source: self drawn

\subsection{Influence of macro policies and other factors on social integration}

The Beijing municipal government issued policies about Beijing second Green Belt, these policies and regulations more detailed rules for the green in the villages and towns development path, shall be maintained, the early after urbanization in large-scale demolition back room is given priority to, combined with the above and new countryside construction to improve rural living environment, at the same time, strictly control the expansion of rural construction. Therefore, the rural residential land in Cuigezhuang increased slowly at first and decreased significantly after 2016. As a policy means, the space control between Beijing second Green Belt restricts people's desire for unlimited development and construction, restricts the development of non-agricultural industries in rural areas, leads to the urban-rural dual structure, produces residential differentiation, and further affects the social integration of residents.

\section{Planning strategies to promote the social integration of residents}

\subsection{Enrich the configuration of public facilities and integrate the needs of diverse}

\section{communities}

First of all, service facilities take into account the living and employment needs of migrant residents, avoid separation of jobs and residence, and improve economic integration; Second, in planning the construction of public facilities, attention should be paid to adapt to the different demand preferences and payment ability of multiple groups, form the equalization of public services in the whole community, narrow the gap with the residents of commercial residential areas, and improve the overall national quality and psychological integration of residents. Third, transform the supporting public service facilities of each community, and arrange rest and sports facilities to promote the communication between people. In particular, the lack of public facilities in low-grade residential areas (rural self-built housing) and unit compound.

\subsection{Improve the quality of living environment to meet diverse needs}

Improve the living environment is the first condition of public activities, through a series of planning control and incentive measures, carefully choose the low quality of public space and poor quality, poor sanitation of the rural construction, to build rural oneself and unit compound residents to create a high quality, comfortable, health, living environment, meet the needs of the foreign residents nearby have a rest and activity. 


\subsection{Strengthen the construction of social organizations and promote the development of}

\section{community activities}

The first is to advocate public space as the carrier to hold various activities with local characteristics in the community, such as community parent-child handcraft, community reading club, community square dance contest, calligraphy and painting exhibition, etc. Second, community residents manage community public affairs together with the government and community organizations to strengthen the sense of identity and belonging of tenants inside and outside the community, and establish a mutual trust relationship in the community. Third, by creating the value orientation of neighbors helping each other and everyone being equal in the community, guide residents to participate in the construction of community space and improve psychological integration.

\subsection{Build diverse mixed communities and improve the policy guarantee system}

Construct a variety of mixed living space. First, through the mixed layout of commercial housing, social security housing and other types of housing in the community, distinguish different forms of property rights such as full ownership, restricted ownership, partial ownership, lease right, and so on, in a disguised way to promote the realization of mixed living of people with different incomes. Second, by controlling the construction cost of different residential buildings and the building density and floor area ratio of different areas and house types in the community, diverse housing options can be provided for different income groups, so as to flexibly realize the mixed living in the community. In terms of policy, first, providing adequate social security will promote the economic integration of this group, especially the migrant population with their families who have lived in Beijing for a long time. Second, improve the diversity and efficiency of public services, expand the space for residents to choose public services, and gradually realize the citizen treatment in employment, medical treatment, education, social security and other aspects of cuigezhuang rural residents, which will provide the possibility for their families to integrate into the modern life of urban communities.

This paper describes the current characteristics of residential space differentiation and social integration in Cuigezhuang township and typical communities and analyzes the influencing mechanism of residents' social integration under different residential space types.

\section{The main conclusions are as follows:}

1. In Cuigezhuang Township, there are five types of diversified residential settlement space, including rural self-built housing, return residential area, commercial residential area, unit public housing area and highgrade villa area. Taking village area as the boundary, it is found that there are two types of residential space differentiation in Hegezhuang, two types of residential space differentiation in Feijia village, two types of residential space differentiation in Feijia Village, two types of residential space differentiation in Feijia Village, and two types of residential space differentiation in Jingwang community.

2. From the perspective of different living space types of the three representative villages (communities), the degree of social integration of residents is significantly different. "Unit compound" and "return residential area" residents have the highest degree of social integration, it is concluded that this kind of concentrated resettlement residential area will promote communication and social participation; Residents living in the "commercial housing district" social integration degree is relatively low, that though relatively high degree of commercialization of housing, living environment is also very good, but because is a large residential community and population diversity, collective participation in community activities is not high, so low social integration, "rural from building" because of the floating population most liquid, lowest social alignment. 
3. From the perspective of the social integration dimensions of the three typical villages (communities), the scores of the social integration dimensions of the three typical communities in Cuigezhuang township basically show that the integration of social interaction dimension, psychological dimension, social participation dimension and economic work dimension decrease successively.

4. In terms of analyzing the impact of residential factors on residents' social integration, residents living in different residential Spaces have different factors to promote their social integration. In the rural self-built houses, the living factors influencing the overall degree of social integration are as follows: hygienic environment conditions, public security, utilization rate of cultural service facilities, rent price, per capita living area, living reasons. The factors that have an effect on the overall degree of social integration are landscape greening, transportation convenience, living time and living reason in descending order. The factors influencing the overall degree of social integration in "unit public housing community" in descending order are: the utilization rate of public space, cultural service facilities, rent price and sanitary environment conditions; The factors influencing the overall degree of social integration of "commercial housing + return residential area" are living reasons and time, rent price and transportation convenience.

5. In addition to the residential factors affecting the social integration of residents, the policy of strictly controlling the expansion of rural construction within the Beijing second Green Belt also limits people's desire to build. In particular, the large-scale demolition of communities (villages) in many green areas, especially for low-income migrants, does not help social integration and rapid urbanization.

6. According to the key factors affecting social integration, the author tries to put forward the strategies of enriching the allocation of public facilities, integrating the needs of diversified facilities, improving the quality of living environment, strengthening the construction of social organizations, promoting community activities and participation, building diversified mixed communities, and improving the policy guarantee system.

\section{References}

[1]夏方舟,刘唱.靶向居住分异的国土空间规划中混合社区优化设计研究[J].南方建筑,2021(02):56-62.

[2]冯健,周一星.转型期北京社会空间分异重构[J].地理学报,2008:63(8):829-844.

[3]KnoxP,PinchS.Urbansocialgeography:Anintroduction[M].4thed.Essex,UK:PearsonEducation.2000.

[4]申悦,柴彦威.基于日常活动空间的社会空间分异研究进展[J].地理科学进展,2018,37(6):853-862.

[5]马克・戈特迪纳,雷・哈奇森.新城市社会学[M].黄怡,译.上海:上海译文出版社,2011.

[6]GIFFINGERR.SegregationinVienna:Impactsofmarketbarriersandrentregulation[J].UrbanStudies,1998,35 (10):1791-1812.

[7]禤铃沂,龚岳,李贵才.中国特大城市居住分异特征与演化研究:2000-2015[J].城市问题,2020(02):3138.

[8]DuncanD,DuncanB.Amethodologicalanalysisofsegregationindexes[J].AmericanSociologicalReview,1955 (20):210-217.

[9]MasseyDS,DentonNA.HypersegregationinUSmetropolitanareas:Blackandhispanicsegregationalongfived imensions[J].Demography,1988(26):373-391.

[10]MasseyDS,DentonNA.1988. Thedimensionsofresidentialsegregation[J].SocialForces,67(2):281-315.

[11]张海娜, 朱贻文,邓晓翔.快速城镇化背景下居住空间分异与失地农民社会融合的作用机制研究一 一以长三角地区为例[J].地理科学进展,2021,40(01):135-146. 
[12]张祥智,叶青.我国混合居住研究进展[J].城市问题,2017(6):36-45.

[13]LiZG,WuFL.Tenure-basedresidentialsegregationinpost-

reformChinesecities:AcasestudyofShanghai[J].TransactionsofthelnstituteofBritishGeographers,2008,33(3) :404-419.

[14]吴启焰,吴小慧,ChenGuo,HammeIJD,刘咏梅,刘丹. 基于小尺度五普数据的南京旧城区社会空间分 异研究[J].地理科学,2013,33(10):1196-1205.

[15]李东泉,李贤. 街区尺度的居住空间分异现象研究——以北京三里河四个居住小区为例[J]. 新建 筑,2014(02):126-129

[16]张纯, 柴彦威, 陈零极. 从单位社区到城市社区的演替: 北京同仁堂的案例 [J]. 国际城市规 划,2009,24(05):33-36.

[17] 秦洛峰, 周雪吟, 俞淳流. 基于城市空间分异理论的深圳城中村租赁改造研究 [J]. 建筑与文 化,2019(08):119-121.

[18]张艳,柴彦威, 周千钧. 中国城市单位大院的空间性及其变化: 北京京棉二厂的案例[J]. 国际城市规 划,2009,24(05):20-27.

[19] 张纯,柴彦威. 中国城市单位社区的空间演化: 空间形态与土地利用 [J]. 国际城市规 划,2009,24(05):28-32.

[20]李志刚, 薛德升,MichaelLyons,AlisonBrown. 广州小北路黑人聚居区社会空间分析[J]. 地理学 报,2008(02):207-218.

[21]李志刚, 吴缚龙, 卢汉龙. 当代我国大都市的社会空间分异一一对上海三个社区的实证研究[J]. 城市 规划,2004(06):60-67.

[22]黄怡. 大都市核心区的社会空间隔离——以上海市静安区南京西路街道为例[J]. 城市规划学 刊,2006(03):76-84.

[23]WangW,ZhouS,FanCC.GrowthanddeclineofMuslimHuienclavesinBeijing[J].EurasianGeographyandEco nomics,2002,43(2):104-122.

[24]PowCP.Securingthe "civilized"enclaves:Gatedcommunitiesandthemoralgeographiesofexclusionin(post -)socialistShanghai[J].UrbanStudies,2007,44(8):1539-1558.

[25]YipNM.Walledwithoutgates:GatedcommunitiesinShanghai[J].UrbanGeography,2012,33(2):221-236.

[26]吴启焰,吴小慧,ChenGuo,HammelJD,刘咏梅,刘丹. 基于小尺度五普数据的南京旧城区社会空间分 异研究[J].地理科学,2013,33(10):1196-1205.

[27]ShevkyE,WilliamsM.TheSocialAreasofLosAngeles[M].LosAngeles:UniversityofCaliforniaPress, 1949.

[28]吴启焰,等.城市居住空间分异的理论基础与研究层次[J].人文地理,2000(3):1-5.

[29]ZhouM.Revisitingethnicentrepreneurship:Convergencies, controversies, andconceptualadvancements[ J].InternationalMigrationReview,2004,38(3):1040-1074.

[30]EchazarraA.ResidentialsegregationoftheforeignpopulationinMadrid'smetropolitcanarea:Aquantitative anslysis[J].RevistaInternacionalDeSociologia,2010,68(1):165-197.

[31]余运江, 高向东, 郭庆. 新生代乡一城流动人口社会融合研究: 基于上海的调查分析. 人口与经 济,2012(1):57-64. 
[32]张文宏,雷开春.城市新移民社会融合的结构、现状与影响因素分析.社会学研究,2008(5):117-141.

[33]李志刚,刘华.中国城市“新移民”社会网络与空间分异.地理学报,2011,66(6):785-795.

[34]任远, 乔楠.城市流动人口社会融合的过程、测量及影响因素[J].人口研究, 2010，34 (02) : 11-20.

[35]陆自荣, 张颖.城市社区感知融合度的影响因素——基于三个群体的比较[J].城市问题, 2016 (03) : 92-103.

[36]康雷,张文忠,谌丽, 湛东升,刘彩彩. 北京市低收入社区社会融合的多维度测度与影响因素分析 [J]. 人文地理,2019,34(03):22-29.

[37]刘生军,董香,李莎莎. 回迁住区居民社会融合度调查及规划对策研究一一以沈阳为例[J].城市发展 研究, 2020,27(01):12-15+21.

[38] 汪明峰, 程红, 宁越敏.上海城中村外来人口的社会融合及其影响因素 [J]. 地理学 报,2015,70(08):1243-1255.

[39]周皓.流动人口社会融合的测量及理论思考[J].人口研究,2012,36(03):27-37. 